\title{
Alterations of murein structure and of penicillin-binding proteins in minicells from Escherichia coli
}

\author{
Wolfgang Obermann† and Joachim-Volker Höltje
}

Author for correspondence: Joachim-Volker Höltje. Tel: +49 7071 601412. Fax: +497071601447.

Max-Planck-Institut für Entwicklungsbiologie, Abteilung Biochemie, Spemannstraße 35, 72076 Tübingen, FRG

\begin{abstract}
Minicells, as compared with a whole cell preparation of a minA/B mutant of Escherichia coli, showed a number of changes in the structure of the murein sacculus. Minicell murein was enriched in LD-A $\mathrm{Pm}-\mathrm{A}_{2} \mathrm{pm}$ crossbridges by about $66 \%$ and reduced in the amount of L-Ala-D-Glu dipeptide moieties by about $55 \%$. In addition, the length distribution of the glycan strands in the murein was shifted to shorter lengths. In particular, the relative amount of the shortest possible strand, the size of a disaccharide, was more than doubled. Minicells were also found to have an altered penicillin-binding protein (PBP) pattern. Whereas PBP4 and PBP6 were greatly diminished, PBP8 was significantly increased. We consider it unlikely that the sort of changes observed in murein structure reflect the fact that minicells are composed of two hemispherical polar caps.
\end{abstract}

Keywords: Escbericbia coli, murein, penicillin-binding proteins, minicells, cell division

\section{INTRODUCTION}

During the cell cycle of bacteria, morphological changes occur that are due to corresponding alterations in the shape of the bacterial exoskeleton, the murein sacculus (Weidel \& Pelzer, 1964; Schwarz et al., 1969; Nanninga, 1988). In the case of rod-shaped bacteria such as Eschericbia coli, cell elongation alternates with septum formation which is followed by splitting of the septum to allow separation of the daughter cells. These processes are accompanied by alterations in the metabolism of murein. During cell elongation cylindrical murein is synthesized, whereas for cell division to take place septal murein is formed which - after cleavage - gives rise to two new hemispherical polar caps. Specific enzyme systems are

\footnotetext{
†Present address: Max-Planck-Institut für biophysikalische Chemie; Am Faßberg, 37077 Göttingen, FRG.

Abbreviations: $\mathrm{A}_{2} \mathrm{pm}$, diaminopimelic acid; $\mathrm{PBP}$, penicillin-binding protein; Abbreviations for muropeptides (Glauner et al., 1988) are as follows: Di, GlcNAc( $\beta 1$-4)MurNAc-L-Ala-D-Glu; Tri, GlcNAc( $\beta 1$-4)MurNAc-L-Ala-DGlu-A, pm; Tetra, GlcNAc( $\beta 1-4)$ MurNAc-L-Ala-D-Glu-A,pm-D-Ala; Penta, GICNAc( $\beta 1$-4)MurNAC-L-Ala-D-Glu-A pm-D-Ala-D-Ala; Anh, 1,6-anhydromuramic acid present; Gly4/Gly5, D-Ala in position 4 or 5 of the peptidyl residue is replaced by Gly; Tetra-Tri, Tetra-Tetra, Tetra-Penta, dimers of the indicated substituents formed by a D-Ala-m- $\mathrm{A}_{2} \mathrm{pm}$ interpeptide bond; Tetra-Tetra-Tri, Tetra-Tetra-Tetra, trimers consisting of the indicated substituents formed by two D-Ala-m- $A_{2} p m$ interpeptide bonds: $A_{2} p m$, an $m-A_{2} p m-m-A_{2} p m$ interpeptide bond is present instead of the D-Ala-m$A_{2}$ pm crossbridge.
}

assumed to be involved in these processes (Schwarz et al., 1969; Park \& Burman, 1973; Spratt, 1975; Botta \& Park, 1981; Kraus \& Höltje, 1987; Lleo et al., 1990; Nanninga et al., 1990; Nanninga, 1991). The question that then arises is whether the different shapes of polar caps and the cylindrical part of the sacculus are paralleled by changes in the chemistry of the murein. Up to now, such a correlation has not been proven experimentally; rather, it has recently been suggested that it does not exist (Driehuis \& Wouters, 1987; de Jonge et al., 1989).

Therefore, we addressed the problem with a novel analytical method that allowed us to determine the length distribution of the glycan strands from which the sacculus is made (Harz et al., 1990). As a source for polar cap material we decided to isolate minicells, which are formed in $\min B$ mutants of $E$. coli as a result of a failure in placing the site of division at the equator of the rod-shaped bacterium (de Boer et al., 1989). Instead, a potential division site at one of the poles is chosen erroneously by the cell. PBP3, which is the septum synthesizing enzyme (Botta \& Park, 1981), together with FtsZ (de Boer et al., 1992; Raychaudhuri \& Park, 1992; Mukherjee et al., 1993) are required for both normal cell division at the midpoint and minicell formation at the poles of the cell (Ward \& Lutkenhaus, 1985). Thus, it seems likely that the septum that splits off a minicell is made of normal septal murein. Minicells, which lack cylindrical murein, may therefore indeed consist of regular polar cap murein only. 
Using the minicell producing strain E. coli P678-54, both the murein of the rod-shaped whole cells and the murein of the spherical minicells can be compared directly with each other.

Minicells cannot easily be obtained in sufficiently high quantities because yield from the minicell producing strain E. coli P678-54 is less than 1\%. Therefore, we established a procedure that allows the introduction of a label with a high specific radioactivity to murein after its preparation. This can be done by specific galactosylation of the terminal glucosamine residues of the polysaccharides using galactosyltransferase and labelled UDPgalactose (Schanbacher \& Ebner, 1970; Schindler et al., 1976). Not only the composition of the murein but also the pattern of PBPs was found to differ between minicells and whole cell preparations.

\section{METHODS}

Bacterial strains and growth conditions. Escherichia coli MC 4100 and the minicell producing strain P678-54 (min $A$ minB) (Adler $e t$ al., 1967) were grown at $37^{\circ} \mathrm{C}$ with vigorous shaking in LB-medium containing $\left(1^{-1}\right) 10 \mathrm{~g}$ Bacto-tryptone, $5 \mathrm{~g}$ Bacto-yeast extract and $10 \mathrm{~g} \mathrm{NaCl}$. Growth of the cultures was followed by measuring the optical density at $578 \mathrm{~nm}\left(\mathrm{OD}_{578}\right)$ in an Eppendorf photometer. Exponentially growing cells at an $\mathrm{OD}_{578}$ of about 0.7 were harvested by centrifugation in the cold. Radiolabelling of murein was done by growth of the cells in the presence of $0 \cdot 74 \mathrm{kBq} \mathrm{D}-\left[1-{ }^{3} \mathrm{H}\right]$ glucosamine hydrochloride $\mathrm{ml}^{-1}$ (185 GBq mmol ${ }^{-1}$; Amersham).

Isolation of minicells. Minicells of E. coli P678-54 were isolated by isopycnic Percoll gradient sedimentation according to the method of Bellemare et al. (1986) (see also Markicwicz \& Höltje, 1992).

PBP assay. The profile of PBPs in the membranes of whole celis and minicells of E. coli P678-54 was basically determined according to the procedure described by Spratt (1975). However, a ${ }^{125}$ I-labelled derivative of ampicillin, prepared following the method of Schwarz et al. (1981), was used. Membranes (10 $\mu \mathrm{g}$ protein) suspended in $20 \mu \mathrm{l} 0.05 \mathrm{M}$ potassium phosphate buffer containing $0.01 \mathrm{M} \mathrm{MgCl}_{2}, \mathrm{pH} 7.0$ were incubated in the presence of ${ }^{125} \mathrm{I}$-labelled ampicillin $(5 \mu \mathrm{l}$ of freshly prepared material; about $37 \mathrm{kBq}$ ) as described by Schwarz et al. (1981). After solubilization of the membrane proteins according to Spratt \& Pardee (1975), they were separated by SDS-10\% (w/v) polyacrylamide gel electrophoresis (Laemmli, 1970) and the labelled penicillin-enzyme complexes were made visible by autoradiography.

Preparation of murein sacculi. Murein sacculi were prepared as described by Harz et al. (1990).

Analysis of the muropeptide composition. Murein from minicells and whole cells of E. coli P678-54 was degraded with Cellosyl, a muramidasc from Sireptonyces coelicolor, as described by Glauner (1988). The muropeptides were reduced with $\mathrm{NaBH}_{4}$ and separated at $55^{\circ} \mathrm{C}$ at a flow rate of $0.5 \mathrm{ml} \mathrm{min}^{-1}$ on a Hypersil ODS $\mathrm{C}_{18}$ column using a linear gradient from $50 \mathrm{mM}$ sodium phosphate, $\mathrm{pH} 431$, to $75 \mathrm{mM}$ sodium phosphate,
pH 4.95 containing $15 \%$ methanol, following the procedure of Glauner et al. (1988).

Analysis of the length distribution of the glycan strands. Glycan strands were released from murein sacculi by digestion with human serum amidase as described by Harz et al. (1990). To introduce a radioactive label, the $N$-acetylglucosamine ends of the sugar chains were substituted with $\left[{ }^{3} \mathrm{H}\right]-$ or $\left[{ }^{14} \mathrm{C}\right]$ galactose by the galactosyltransferase reaction according to the method of Schindler et al. (1976). The reaction mixture consisted of the glycan strands $(0.05 \mathrm{mM})$ released from isolated murein sacculi by amidase digestion, uridine diphospho- $\mathrm{D}-\left[6{ }^{3} \mathrm{H}\right]-$ or $-[\mathrm{U}-$ ${ }^{14} \mathrm{C}$ galactose (Amersham; $74 \mathrm{kBq}$, adjusted with unlabelled UDP-Gal to a final concentration of $0.5 \mathrm{mM}), 0.1 \mathrm{mM} \mathrm{MnCl}$, $50 \mathrm{mM}$ MOPS, $\mathrm{pH} 7 \cdot 4$, and galactosyltransferase $(1.8 \times$ $10^{-3} \mathrm{U} \mathrm{ml}^{-1}$; Sigma). The mixture was incubated at $37^{\circ} \mathrm{C}$ for $5 \mathrm{~h}$, adjusted with $\mathrm{H}_{3} \mathrm{PO}_{4}$ to $\mathrm{pH} 45$ and boiled for $8 \mathrm{~min}$. Denatured protein was removed by centrifugation for $10 \mathrm{~min}$ in an Eppendorf centrifuge. The supernatant was concentrated and stored frozen at $-20^{\circ} \mathrm{C}$. Prior to HPLC fractionation of the glycan strands, the peptide moieties had to be removed by chromatography on a Mono S HR 5/5 column (Pharmacia) as described by Harz et al. (1990). Fractionation of the glycan strands according to their chain length was performed by HPLC on Nucleosil $300 \mathrm{C}_{\mathbf{1 8}}$. Elution was done at a flow rate of $0.5 \mathrm{ml} \mathrm{min}{ }^{-1}$ at $50{ }^{\circ} \mathrm{C}$ using a convex gradient from $5 \%$ to $11 \%$ $(\mathrm{w} / \mathrm{v})$ acetonitrile in $100 \mathrm{mM}$ sodium phosphate, $\mathrm{pH} 2 \cdot 00$ (Harz et al., 1990).

\section{RESULTS}

\section{Specific labelling of isolated glycan strands}

Galactosylation of the $N$-acetylglucosamine residues was used as a means to label isolated murein specificaliy. This

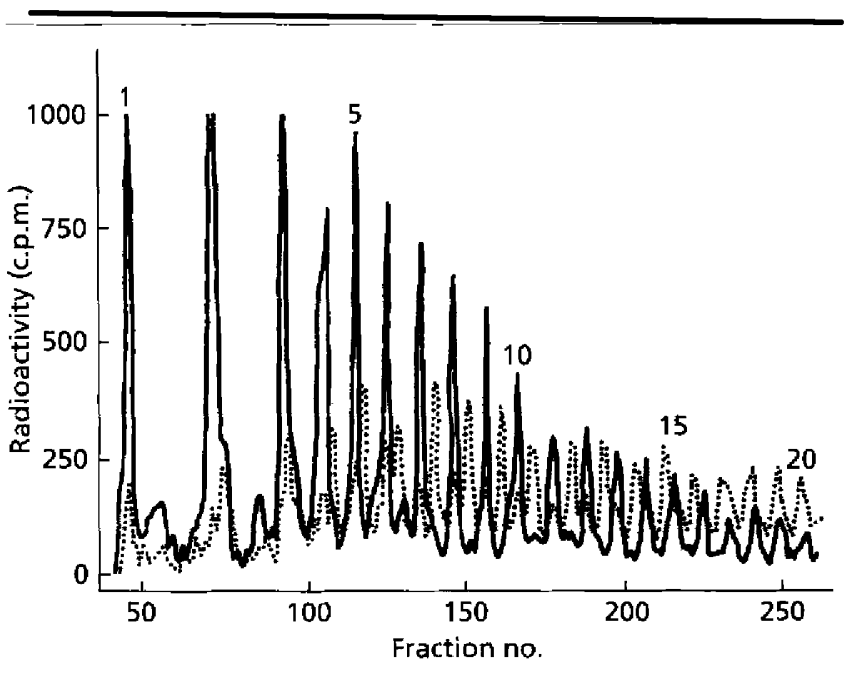

Fig. 1. Co-chromatography of $\left[{ }^{3} \mathrm{H}\right] \mathrm{GlCNAC}-$ and $\left[{ }^{14} \mathrm{C}\right] \mathrm{Gal}-$ $\left.{ }^{3} \mathrm{H}\right] \mathrm{GlCNAC}$-double-labelled glycan strands. $E$. coli MC4100 was grown in LB medium in the presence of $\left.7.4 \mathrm{kBq}^{3} \mathrm{H}\right] \mathrm{GlcNAC} \mathrm{\textrm {Cl } ^ { - 1 }}$ (185 GBq mmol${ }^{-1}$ ) and harvested during exponential growth. Murein was isolated, the glycan strands prepared and one portion of the glycans was galactosylated with $74 \mathrm{kBq}$ UDP$\left.{ }^{[14} \mathrm{C}\right] \mathrm{Gal} \mathrm{ml}{ }^{-1}\left(1.2 \mathrm{~Bq} \mathrm{mmol}^{-1}\right)$ as described in Methods to yield double-labelled glycan strands. The glycans were separated by reversed-phase HPLC on an ODS Nucleosil $(5 \mu \mathrm{m})$ column using a convex acetonitrile gradient in phosphate buffer, also as described in Methods. ...., ${ }^{3} \mathrm{H}$ label; $\longrightarrow,{ }^{14} \mathrm{C}$ label. 


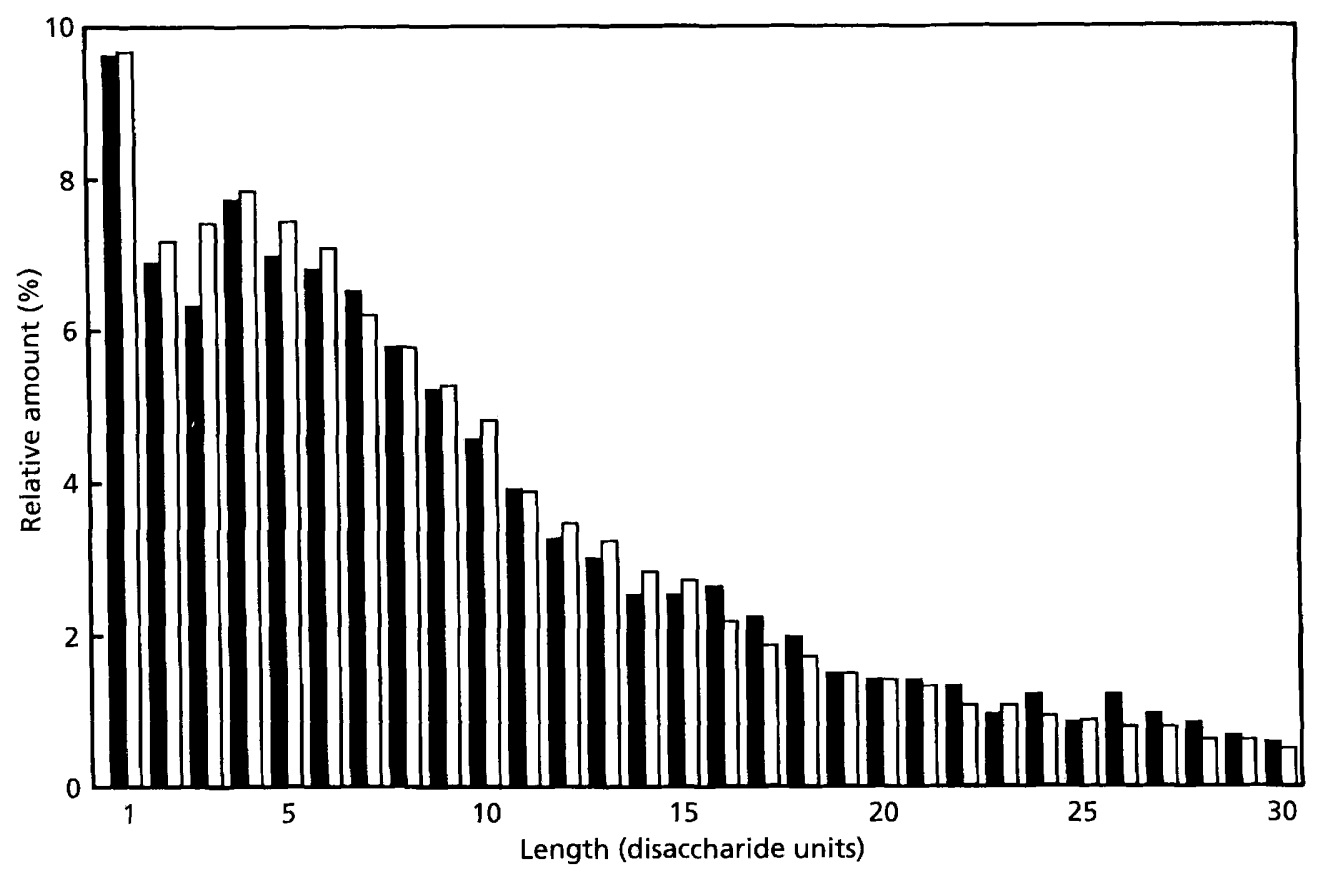

Fig. 2. Comparison of the length distribution of glycan strands from $\left[{ }^{3} \mathrm{H}\right] \mathrm{GlCNAC}$-labelled murein before and after galactosylation with $\left[{ }^{14} \mathrm{C}\right] \mathrm{Gal}$. The double-labelled glycans were quantified on the basis of their ${ }^{14} \mathrm{C}$ label only. The preparation procedures and the conditions for reversed-phase HPLC of the glycans on ODS Nucleosil are given in Methods. $\square,\left[{ }^{3} \mathrm{H}\right] \mathrm{GlcNAc}$-labelled glycans; $\square,\left[{ }^{14} \mathrm{C}\right] \mathrm{Gal}$ label of double-labelled glycans.

method adds one galactose molecule to the nonreducing end of the glycan strands without otherwise affecting the material (Schindler et al., 1976). It became apparent that glycan strands released from murein by amidase treatment are a better substrate for the galactosyltransferase than intact murein sacculi. Accordingly, prior to galactosylation the murein was digested with human serum amidase following the established procedure (Harz et al., 1990). Another problem was caused by the relatively high $\mathrm{Mn}^{2+}$ concentration which, although optimal for the enzyme (Schindler et al., 1976) results in precipitation of the glycan strands. Analysis of the dependency of the reaction on $\mathrm{Mn}^{2+}$ revealed that a decrease to $0.1 \mathrm{mM}$ did not affect the galactosyltransferase activity but avoided precipitation of glycan strands.

The reliability of the galactosylation procedure for labelling isolated glycan strands was investigated by comparing this method with in vivo labelling of murein by growth in the presence of a specific label. Murein was prepared from cells grown in the presence of $\left[{ }^{3} \mathrm{H}\right] \mathrm{GlcNAc}$, and the glycan strands were isolated. One aliquot was galactosylated with UDP- $\left[{ }^{14} \mathrm{C}\right] \mathrm{Gal}$ as described in Methods, yielding double-labelled glycans. No separation into ${ }^{3} \mathrm{H}$ - and ${ }^{14} \mathrm{C}$-labelled compounds was observed during HPLC fractionation of this galactosylated material (results not shown), although glycan strands longer than 4 disaccharide units, when substituted with galactose, eluted in between the galactose-free glycan strands in co-chromatography (Fig. 1). This finding indicates that all glycan strands longer than 4 disaccharide units had been modified by galactose.

To show also that the shorter glycans which, under standard elution conditions do not separate into galactosefree and galactosylated oligosaccharides (see Fig. 1), had been fully galactosylated, specific conditions to separate di- and trisaccharides by HPLC were established. These conditions were used to further fractionate the first peak obtained from a standard chromatography of doublelabelled glycan strands (Fig. 1), which was expected to contain the galactosylated disaccharide. Whereas anhydro-disaccharide and Gal-anhydro-disaccharide could be separated under these conditions, the ${ }^{3} \mathrm{H}$ - and ${ }^{14} \mathrm{C}$-label of the double-labelled material did not split up into two peaks (results not shown), indicating that the disaccharides also had been modified to $\mathrm{Gal}(\beta 1$ 4)GlcNAc $(\beta 1-4)$ MurNAc. Consequently, a quantification of the double-labelled glycans on the basis of the $\left[{ }^{14} \mathrm{C}\right] \mathrm{Gal}$ label resulted in an identical pattern of glycan strand distribution when compared with $\left[{ }^{3} \mathrm{H}\right]$ GlcNAc-labelled material (Fig. 2). This result proves the reliability of the galactosylation procedure.

\section{Muropeptide composition of minicells}

Minicells produced by E. coli P678-54 (Adler et al., 1967) were isolated by repeated Percoll density gradient centrifugation until only about one normal rod-shaped cell was present per $10^{5}$ minicells as judged by electron micro- 
Table 1. Muropeptide composition of minicells and rod-shaped whole cells

\begin{tabular}{|c|c|c|}
\hline \multirow[t]{2}{*}{ Muropeptide } & \multicolumn{2}{|c|}{$\begin{array}{c}\text { Relative amount } \\
\text { (percentage of total murein) }\end{array}$} \\
\hline & Whole cells & Minicells \\
\hline Tri & $7 \cdot 36 \pm 0 \cdot 28$ & $7 \cdot 23 \pm 1.03$ \\
\hline $\operatorname{Tetra}\left(G l y_{4}\right)$ & $2 \cdot 78 \pm 0.50$ & $2 \cdot 31 \pm 0.07$ \\
\hline Tetra & $26 \cdot 06 \pm 1 \cdot 05$ & $23 \cdot 39 \pm 0 \cdot 40$ \\
\hline Penta $\left(\mathrm{Gl}_{y_{5}}\right)$ & $0.56 \pm 0.08$ & $0.33 \pm 0.09$ \\
\hline $\mathrm{Di}$ & $1.53 \pm 0.15$ & $0.69 \pm 0.04$ \\
\hline Penta & $0 \cdot 12 \pm 0 \cdot 01$ & $0.35 \pm 0.21$ \\
\hline Tri-Lys-Arg & $5 \cdot 19 \pm 1 \cdot 11$ & $5.88 \pm 0.97$ \\
\hline $\operatorname{Tri}($ Anh $)$ & $0.34 \pm 0.05$ & $0.32 \pm 0.06$ \\
\hline Tetra-Tri $\left(\mathrm{Gly}_{4}\right)$ & $0 \cdot 20 \pm 0 \cdot 01$ & $0.59 \pm 0 \cdot 13$ \\
\hline $\operatorname{Tri}-\operatorname{Tri}\left(\mathrm{A}_{2} \mathrm{pm}\right)$ & $0.65 \pm 0.09$ & $1.00 \pm 0.07$ \\
\hline Tetra-Tri $\left(\mathrm{A}_{2} \mathrm{pm}\right)$ & $2 \cdot 26 \pm 0 \cdot 28$ & $3 \cdot 85 \pm 0 \cdot 20$ \\
\hline Tetra-Tetra $\left(\mathrm{Gly}_{4}\right)$ & $2.35 \pm 0.31$ & $1 \cdot 88 \pm 0 \cdot 09$ \\
\hline Tetra-Tri & $4.99 \pm 0.77$ & $3.08 \pm 0.03$ \\
\hline Tetra-Penta $\left(\mathrm{Gly}_{5}\right)$ & $0.52 \pm 0 \cdot 10$ & $0 \cdot 45 \pm 0 \cdot 10$ \\
\hline Tetra-Tetra & $21 \cdot 63 \pm 0.81$ & $20 \cdot 35 \pm 0 \cdot 06$ \\
\hline Tetra(Anh) & $0.46 \pm 0.07$ & $0.37 \pm 0.05$ \\
\hline Tetra-Penta & $0 \cdot 37 \pm 0 \cdot 01$ & $0.75 \pm 0.08$ \\
\hline Tri-Tri-Lys- $\operatorname{Arg}\left(\mathrm{A}_{2} \mathrm{pm}\right)$ & $0.71 \pm 0.02$ & $1 \cdot 28 \pm 0 \cdot 23$ \\
\hline Tetra-Tetra-Tri $\left(\mathrm{A}_{2} \mathrm{pm}\right)$ & $0.54 \pm 0.03$ & $0 \cdot 88 \pm 0 \cdot 30$ \\
\hline Tetra-Tetra-Tri & $0.58 \pm 0.04$ & $0.40 \pm 0 \cdot 01$ \\
\hline Tetra-Tri-Lys-Arg & $4 \cdot 12 \pm 1 \cdot 19$ & $4 \cdot 25 \pm 1 \cdot 26$ \\
\hline Tetra-Tetra-Tetra & $3.06 \pm 0.30$ & $2 \cdot 79 \pm 0.38$ \\
\hline Tetra-Tetra-Penta & $0.02 \pm 0.01$ & $0.07 \pm 0.03$ \\
\hline Tetra-Tri $\left(\mathrm{A}_{2} \mathrm{pm}\right.$, Anh I $)$ & $0.18 \pm 0.06$ & $0.44 \pm 0.09$ \\
\hline Tetra-Tri $\left(\mathrm{A}_{2} \mathrm{pm}\right.$, Anh II $)$ & $0 \cdot 18 \pm 0.08$ & $0 \cdot 20 \pm 0 \cdot 11$ \\
\hline Tetra-Tri-Tri-Lys-Arg $\left(\mathrm{A}_{2} \mathrm{pm}\right)$ & $0 \cdot 19 \pm 0.05$ & $0 \cdot 32 \pm 0 \cdot 16$ \\
\hline Tetra-Tri(Anh I) & $0.63 \pm 0.06$ & $0.67 \pm 0 \cdot 17$ \\
\hline Tetra-Tri(Anh II $)$ & $0 \cdot 32 \pm 0.05$ & $0.32 \pm 0.08$ \\
\hline Tetra-Tetra-Tetra-Tetra & $0 \cdot 14 \pm 0 \cdot 03$ & $0 \cdot 12 \pm 0 \cdot 03$ \\
\hline Tetra-Tetra-Tri-Lys-Arg & $0.70 \pm 0.05$ & $0 \cdot 60 \pm 0 \cdot 15$ \\
\hline Tetra-Tetra(Anh I) & $0 \cdot 69 \pm 0.20$ & $1 \cdot 21 \pm 0 \cdot 21$ \\
\hline Tetra-Tetra(Anh II) & $1 \cdot 04 \pm 0 \cdot 11$ & $1 \cdot 13 \pm 0 \cdot 15$ \\
\hline Tetra-Tetra-Tri $\left(\mathrm{A}_{2} \mathrm{pm}, \mathrm{Anh}\right)$ & $0 \cdot 16 \pm 0 \cdot 05$ & $0 \cdot 26 \pm 0 \cdot 09$ \\
\hline Tetra-Tetra-Tri(Anh) & $0 \cdot 16 \pm 0.03$ & $0.19 \pm 0.03$ \\
\hline Tetra-Tetra-Tetra(Anh) & $0.82 \pm 0.12$ & $0 \cdot 80 \pm 0 \cdot 14$ \\
\hline Tetra-Tetra-Tetra-Tetra(Anh) & $0.09 \pm 0.02$ & $0 \cdot 11 \pm 0 \cdot 03$ \\
\hline Tetra-Tri-Lys-Arg(Anh I) & $0 \cdot 31 \pm 0 \cdot 01$ & $0 \cdot 45 \pm 0 \cdot 17$ \\
\hline Tetra-Tri-Lys-Arg(Anh II) & $0 \cdot 24 \pm 0 \cdot 05$ & $0 \cdot 48 \pm 0 \cdot 11$ \\
\hline Tetra-Tetra-Tri-Lys-Arg(Anh I) & $0.09 \pm 0.01$ & $0.12 \pm 0.04$ \\
\hline Tetra-Tetra-Tri-Lys-Arg(Anh II) & $0 \cdot 10 \pm 0 \cdot 01$ & $0 \cdot 12 \pm 0 \cdot 05$ \\
\hline Tetra-Tetra-Tri-Lys-Arg(Anh III) & $0 \cdot 10 \pm 0 \cdot 03$ & $0 \cdot 11 \pm 0.03$ \\
\hline
\end{tabular}

scopic examination of the preparation. A control experiment in which cells of E. coli MC4100 were subjected to the very same procedure (which, incidentally, represents an osmotic stress for the cells) proved to cause no detectable changes in the structure of the murein.

The muropeptide composition of minicells and rodshaped whole cells was compared. The averages of three independent analyses are compiled in Table 1 . The major structural parameters of murein and those muropeptides showing significant differences are listed in Table 2. Two changes in the composition of minicell murein are most evident: an increase in the relative amount of $\mathrm{LD}-\mathrm{A}_{2} \mathrm{pm}$ $\mathrm{A}_{2}$ pm crosslinkages by about $66 \%$ and a decrease in the dipeptide residues by nearly $55 \%$. The average chain length of the glycan strands calculated on the basis of the anhydro-muropeptide components (Höltje et al., 1975) showed a decrease from 27.8 to 23.5 disaccharide units. 
Table 2. Muropeptides showing significant differences when comparing minicells with rod-shaped whole cells

\begin{tabular}{|c|c|c|c|}
\hline \multirow[t]{2}{*}{ Muropeptide } & \multicolumn{2}{|c|}{$\begin{array}{l}\text { Relative amount } \\
\text { (percentage of } \\
\text { total murein) }\end{array}$} & \multirow[t]{2}{*}{$\Delta(\%)$} \\
\hline & $\begin{array}{l}\text { Whole } \\
\text { cells }\end{array}$ & Minicells & \\
\hline Monomers & $47 \cdot 63$ & $45 \cdot 19$ & $-5 \cdot 1$ \\
\hline $\mathrm{Di}$ & 1.53 & 0.69 & $-54 \cdot 9$ \\
\hline Dimers & $45 \cdot 04$ & $47 \cdot 08$ & +4.5 \\
\hline Tetra-Tetra & $21 \cdot 63$ & $20 \cdot 35$ & $-5 \cdot 9$ \\
\hline Tetra-Tri $\left(A_{2} p m\right)$ & $2 \cdot 26$ & 3.85 & $+70 \cdot 4$ \\
\hline Tetra-Tri & 4.99 & $3 \cdot 08$ & $-38 \cdot 3$ \\
\hline Trimers & $7 \cdot 08$ & $7 \cdot 49$ & +5.8 \\
\hline Tetra-Tetra-Tri $\left(\mathrm{A}_{2} \mathrm{pm}\right)$ & 0.54 & 0.88 & $+62 \cdot 9$ \\
\hline Tetra-Tetra-Tri & $0 \cdot 58$ & $0 \cdot 40$ & $-31 \cdot 0$ \\
\hline Tetramers & $0 \cdot 25$ & $0 \cdot 25$ & $\pm 0 \cdot 0$ \\
\hline Crosslinkage & $27 \cdot 43$ & 28.71 & \pm 4.7 \\
\hline $\mathrm{Ala}-\mathrm{A}_{2} \mathrm{pm}$ & $24 \cdot 66$ & $24 \cdot 30$ & -1.5 \\
\hline $\mathrm{A}_{2} \mathrm{pm}-\mathrm{A}_{2} \mathrm{pm}$ & $2 \cdot 62$ & $4 \cdot 35$ & $+66 \cdot 0$ \\
\hline Average chain length & $27 \cdot 8$ & $23 \cdot 5$ & $-15 \cdot 5$ \\
\hline
\end{tabular}

This latter finding of a shift to shorter glycan strands in minicells was analysed in more detail by a determination of the complete profile of the different lengths of the glycan strands.

\section{Length distribution of the glycan strands in the murein of minicells}

The glycan strands can be released in their native lengths from the murein network by human serum amidase (Mollner \& Braun, 1984; Harz et al., 1990). The polysaccharides can then be separated from the peptide moieties by ion exchange chromatography and finally be fractionated by reversed-phase HPLC according to size, that is degree of polymerization. To introduce a radioactive label, the isolated glycan strands were galactosylated using UDP- $\left[{ }^{3} \mathrm{H}\right] \mathrm{Gal}$ as described in detail in Methods prior to HPLC-separation. The fractionation profiles of the glycan strands from minicells and whole cells are shown in Fig. 3.

The cells of the minicell producing culture were quite irregular with respect to shape, consisting of normally sized rods and elongated rods arising from cells that have divided asymmetrically during minicell formation. Therefore, we also determined the length distribution of the glycan strands from murein of the E. coli K12 strain MC4100 (Fig. 3). Comparison of the minicell murein with either of the two murein preparations, from whole cells of the minicell producer or from E. coli MC4100, revealed a shift of the length distribution to shorter glycan strands in the case of the minicells.

Since only the GlcNAc terminus of the strands is labelled by this method, the radioactivity reflects the number of molecules of the different size classes and not the amount of glycan. A meaningful comparison of the murein of minicells with the murein of whole cells, however, calls for identical amounts of murein to be compared. Therefore, the amount of murein represented by each size class of glycan strands was calculated on the basis of their known lengths (molecular masses).

Furthermore, in order to compare specifically the spherical murein of polar caps with cylindrical murein synthesized during cell elongation, the murein material of minicells, which are believed to consist of polar caps only, had to be subtracted from the murein of whole cells, which consist of both polar caps and cylindrical murein. Assuming an identical thickness of the murein for both the cylindrical and the polar part of the sacculus (Wientjes et al., 1991), the length distribution of the cylindrical murein can be calculated on the basis of the known proportions of polar caps and cylinder. Detailed surface measurements of isolated murein sacculi have shown that the polar caps of a rod-shaped sacculus represent about $2 / 9$ of the total surface (Woldringh et al., 1987). Although the ratio of polar to cylindrical surface can vary according to strain and growth conditions, we used this value for an approximate calculation. Accordingly, the amounts of material for each chain length were multiplied in the case of minicell murein by a factor of 2 and in the case of whole cell murein by a factor of 9 . The resulting distribution profiles were then subtracted from each other to obtain the distribution of the relative amounts of the different chain lengths for cylindrical murein. As shown in Fig. 4, the relative amount of glycan strands in the range 1-10 disaccharide units is significantly increased in minicell murein; in other words, a larger portion of the total murein of polar caps is made of shorter glycan strands as compared with cylindrical murein. In particular, the shortest glycan strand possible, the disaccharide, was increased by a factor of almost five.

\section{PBP pattern}

Changes in the relative amounts of the PBPs in minicells of E. coli have been reported (Buchanan, 1981). Unfortunately, in that publication the pattern of the PBPs in the unfractionated initial culture, which was supposed to represent the control, was notably different from the wellestablished pattern (Spratt, 1975), having a greatly reduced amount of PBP3. Therefore, in this study we analysed the PBP pattern in both the whole cell preparation and the minicells. As shown in Fig. 5, the pattern of PBPs differed substantially. Most prominent was the dramatic reduction in the amounts of PBP4 and PBP6 and the increase in the amount of PBP8 in the membranes of minicells. The identity of PBP8 was proven by cochromatography with partially purified PBP8 (P. Bindels \& J.-V. Höltje, unpublished results). Our results are in conflict with those published by Buchanan (1981), which showed principally an altered PBP1B in minicells of E. coli $\mathrm{X} 925$. However, since the control in that report showed an abnormal PBP pattern also, as mentioned above, the 


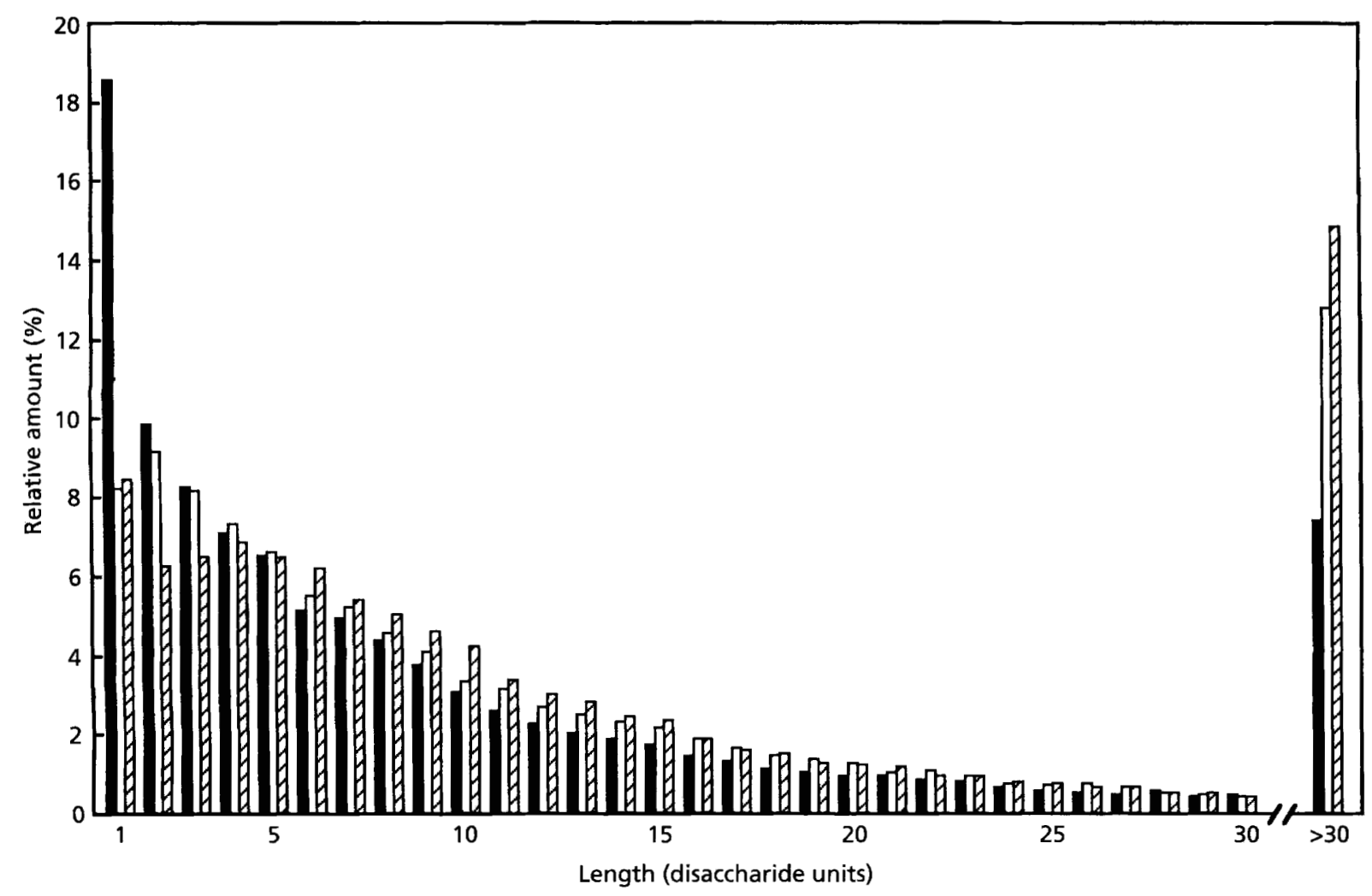

Fig. 3. Length distribution of the glycan strands from murein of minicells ( $\square$ ) and whole cells of $E$. coli $P 678-54$ ( $\square$ ) as weil as E. coli MC4100 (D). The murein glycan strands were prepared, galactosylated with $\left[{ }^{14} \mathrm{C}\right] \mathrm{Gal}$ and separated by reversed-phase HPLC on ODS Nucleosil as described in Methods.

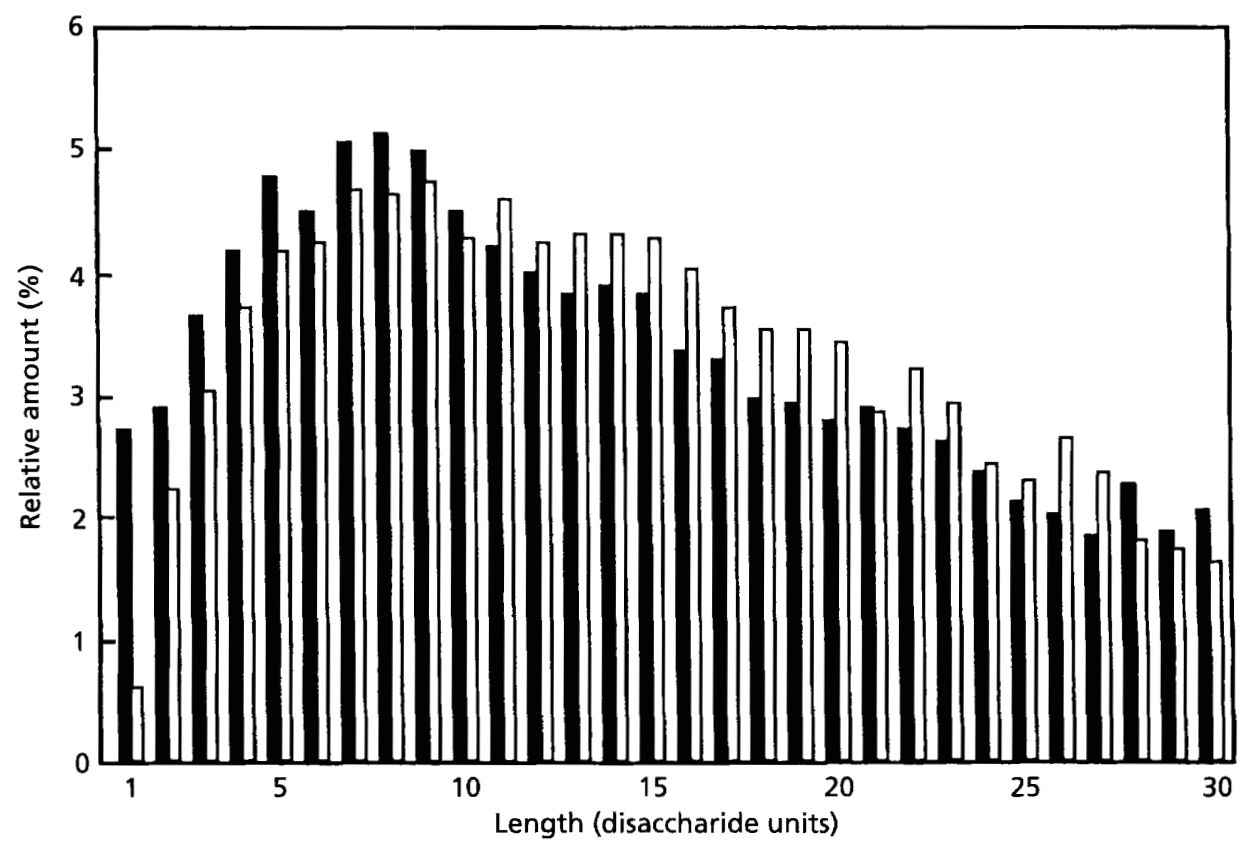

Fig. 4. Glycan composition of cylindrical murein and spherical murein. The relative length distributions of glycan strands in identical amounts of minicell murein and of cylindrical murein of whole cells are shown. The composition of cylindrical murein was obtained by subtracting the values for the polar cap murein as represented by the minicell murein from the total murein of the whole cells. $\mathbf{0}$, Spherical murein; $\square$, cylindrical murein. 


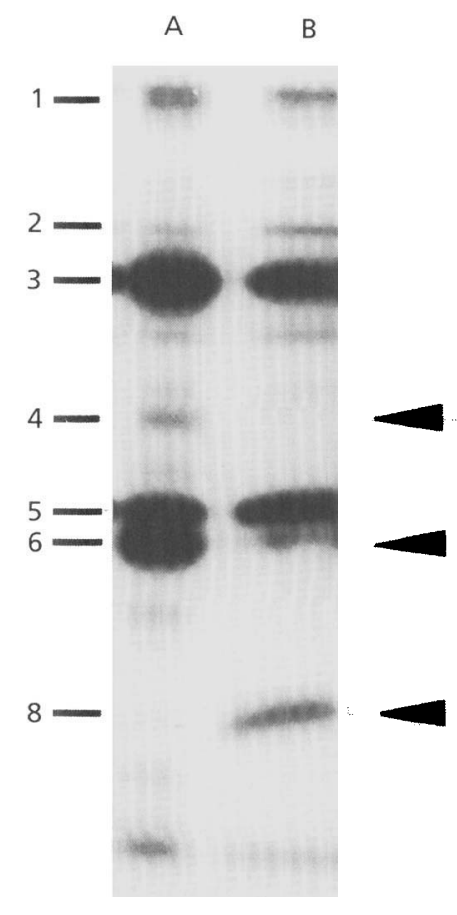

Fig. 5. PBP pattern of whole cells and minicells of E. coli P67854. PBPs were labelled with ${ }^{125}$-labelled ampicillin, solubilized with Sarkosyl and separated by SDS-10\% (w/v) polyacrylamide gel electrophoresis. Approximately the same amounts of protein $(30 \mu \mathrm{g})$ were applied to each lane. The PBPs (numbered 1 to 8 ) were visualized by autoradiography. Major changes between the two preparations are marked by arrowheads. Lane A, whole cells; lane $B$, minicells.

results may have been affected somehow by the method employed.

\section{DISCUSSION}

The question of the existence of a relationship between the chemical structure of the murein and the shape of the resulting murein sacculus has been addressed in several publications from the early days of murein research up to now (Weidel \& Pelzer, 1964; Schwarz \& Leutgeb, 1971; Henning et al., 1972; Driehuis \& Wouters, 1987; de Jonge et al., 1989). The rod-shaped sacculus of E. coli may be considered to consist of a cylindrical middle part and two hemispherical poles, and these two different structures have been compared with each other in order to answer the above question. This has been done by pulselabelling the murein of synchronously growing cultures (de Jonge et al., 1989) or by analysing cells with a changed morphology due either to a change in the growth rate in chemostat culture (Driehuis \& Wouters, 1987) or to mutations in the PBPs (Glauner, 1986; Schwarz \& Glauner, 1988). Treatments with antibiotics that specifically inhibit certain PBPs have also been used to cause changes in the morphology of the cells (Pisabarro et al., 1986). Filamentous or elongated cells mostly consist of cylindrical murein whereas round or short cells preferentially consist of spherical murein.

Although the composition of murein could be shown to depend on the growth rate, it seems not to be affected by the resulting different shapes of the cells (Driehuis \& Wouters, 1987). Furthermore, a detailed analysis of the murein synthesized during the cell cycle of E. coli revealed different modes of insertion of murein precursors but no alteration in the muropeptide composition of newly synthesized murein (de Jonge et al., 1989). It has been suggested therefore that the murein of the rod-shaped sacculus is chemically identical throughout and remains constant during the cell cycle.

However, interpretation of the results obtained from synchronously growing cultures (de Jonge et al., 1989) has been criticized recently (Cooper, 1990). According to this opposing view, the results actually indicate a change in the murein structure, namely an increase in the degree of crosslinkage during septum formation. A minor increase in crosslinkage has indeed been detected when pulse-labelled murein of filaments was compared with pulse-labelling murein of filaments that were resuming septation (Romeis et al., 1991). Again, a small increase in total crosslinkage of septal murein is reported in this paper, comparing minicells with rod-shaped cells.

To obtain information on the individual lengths of the glycan strands of which the murein sacculus is made, we used a novel approach. Recently, a method has been established to release the glycan strands from the murein network in their native lengths by amidase treatment (Harz et al., 1990). This is followed by fractionation of the glycans according to length by reversed-phase HPLC. Since minicells can only be obtained in rather low yields, a procedure was utilized that allows labelling of murein or solubilized glycan strands after their isolation. Galactosylation of the glucosamine ends of the glycan strands is shown here to represent a reliable procedure.

It is important to note that this method yielded the same length distribution of the glycan strands as was obtained when the natural 1,6-anhydromuramic acid marker for the muramic acid termini of the glycan strands was used instead (Höltje et al., 1975; Glauner et al., 1988). The finding that there are as many 1,6-anhydroMurNAc ends as GlcNAc ends in the murein rules out any speculation about the existence of reducing muramic acid ends.

The length distribution of the glycan strands of the murein from minicells was shifted to shortened lengths when compared with the rod-shaped whole cells. In particular, the shortest possible strand, the disaccharide, was increased most dramatically. Furthermore, the muropeptide composition of the murein of minicells also revealed some additional changes which have not been observed in earlier reports that used either synchronous cultures or morphological mutants (Glauner, 1986; Schwarz \& Glauner, 1988; Driehuis \& Wouters, 1987; de Jonge et al., 1989). Significant increases in the relative amounts of $\mathrm{LD}-\mathrm{A}_{2} \mathrm{pm}-\mathrm{A}_{2} \mathrm{pm}$ crosslinkage as well as in the dipeptide moieties were detected in the murein of minicells. 
It seems difficult to answer the question as to whether these differences in composition between minicells and whole cells actually do reflect the difference in shape of the murein sacculus. Although we cannot rule out this possibility, we think it is unlikely for the following reasons. Besides their spherical shape, the physiology of minicells also is changed as compared with that of whole cells (Frazer \& Curtiss, 1974). Minicells continue to synthesize murein (Reeve, 1977), but at a greatly reduced rate (Markiewicz \& Höltje, 1992). Most importantly, not only the protein composition of the membranes of minicells (Goodell \& Schwarz, 1974; Buchanan, 1981) but also the pattern of PBPs is changed, as shown in this report. Therefore, the murein composition may be changed because of the altered metabolism of the DNAless minicells rather than because they are made of two hemispherical polar caps. Furthermore, the observed changes in the structure of the murein sacculus have also all been seen under growth conditions completely unrelated to a specific spherical shape of the sacculus. The increase in disaccharide strands is reminiscent of a quite similar change that has been detected during the course of antibiotic-induced autolysis of $E$. coli (Kohlrausch \& Höltje, 1991). In addition, analysis of the length distribution of the glycan strands in murein that had been pulse-labelled at different time points in a synchronously growing culture did not show a significant change in length distribution (T. Romeis, N. Nanninga \& J.-V. Höltje, unpublished results). The decrease in dipeptide moieties may indeed be due to the absence of an elongation process in minicells and thus be specific for septum formation, since it has been shown that in synchronously growing cells of Proteus mirabilis dipeptidesubstituted muropeptides are formed preferentially during longitudinal extension of the sacculus (Gmeiner \& Kroll, 1981). However, in contrast to this finding, dipeptide moieties were found to be enriched in short, almost spherical cells of E. coli from the stationary growth phase (Glauner, 1986). The most prominent change in the composition of minicell murein, the increase in LD- $\mathrm{A}_{2} \mathrm{Pm}-$ $\mathrm{A}_{2} \mathrm{pm}$ crosslinkages, is known to occur during aging of murein (Glauner \& Höltje, 1990), as a consequence of a decrease in the growth rate (Driehuis \& Wouters, 1987) and when autolysis is threatening the cell. In the presence of penicillin (Kohlrausch \& Höltje, 1991) and after a rise in the activity of endogenous murein hydrolases (Walderich et al., 1988; Korat et al., 1991), this type of crosslinkage is increased. Therefore, the formation of $\mathrm{LD}-$ $\mathrm{A}_{2}$ pm- $\mathrm{A}_{2}$ pm crosslinkages was interpreted to represent a kind of salvage mechanism to stabilize the murein in lysisprone cells (Glauner et al., 1988). Thus, by comparing the composition of the murein of minicells with that of whole cells, conclusive evidence for a specific correlation between the shape of the murein and its chemistry could not be obtained.

\section{ACKNOWLEDGEMENTS}

We thank Uli Schwarz for his generous support and Zdislaw Markiewicz for his advice in the preparation of minicells. The critical comments by Nanne Nanninga helped to improve the manuscript.

\section{REFERENCES}

Adler, H. I., Fisher, W. D., Cohen, A. \& Hardigree, A. A. (1967). Miniature Escherichia coli cells deficient in DNA. Proc Natl Acad Sci US A 57, 321-326.

Bellemare, G., Estable, M. C. \& Paradis, F. W. (1986). Minicell isolation by isopycnic sedimentation in gradients of silicea: an updated protocol. Analects 14, 1-5.

de Boer, P., Crossley, R. E. \& Rothfield, L. I. (1989). A division inhibitor and a topological specificity factor coded for by the minicell locus determine proper placement of the division septum in E. coli. Cell 56, 641-649.

de Boer, P. A. J., Crossley, R. \& Rothfield, L. (1992). The essential bacterial cell division protein FtsZ is a GTPase. Nature 359, 254-256.

Botta, G. A. \& Park, J. T. (1981). Evidence for involvement of penicillin-binding protein 3 in murein synthesis during septation but not during cell elongation. J Bacteriol 145, 333-340.

Buchanan, C. E. (1981). Topographical distribution of penicillinbinding proteins in the Escherichia coli membrane. J Bacteriol 145, 1293-1298.

Cooper, S. (1990). Relationship between the acceptor/donor radioactivity ratio and cross-linking in bacterial peptidoglycan: application to surface synthesis during the division cycle. J Bacteriol 172, 5506-5510.

Driehuis, F. \& Wouters, J. T. M. (1987). Effect of growth rate and cell shape on the peptidoglycan composition in Escherichia coli. $J$ Bacteriol 169, 97-101.

Frazer, A. C. \& Curtiss, R. (1974). Production, properties and utility of bacterial minicells. Curr Top Microbiol Immunol 69, 1-84.

Glauner, B. (1986). Das Murein von E. coli. Doctoral thesis, University of Tübingen, Germany.

Glauner, B. (1988). Separation and quantification of muropeptides with high-performance liquid chromatography. Anal Biochem 172, 451-464.

Glauner, B. \& Höltje, J.-V. (1990). Growth pattern of the murein sacculus of Escherichia coli. J Biol Chem 265, 18988-18996.

Glauner, B., Höltje, J.-V. \& Schwarz, U. (1988). The composition of the murein of Escherichia coli. J Biol Chem 263, 10088-10095.

Gmeiner, J. \& Kroll, H.-P. (1981). N-Acetylglucosaminyl-Nacetylmuramyl-dipeptide, a novel murein building block formed during the cell division cycle of Proteus mirabilis. FEBS Lett 129, 142-143.

Goodell, E. W. \& Schwarz, U. (1974). Cell envelope composition of Escherichia coli $\mathrm{K}$ 12: a comparison of the cell poles and the lateral wall. Eur J Biochem 47, 567-572.

Harz, H., Burgdorf, K. \& Holtje, J.-V. (1990). Isolation and separation of the glycan strands from murein of Escherichia coli by reversed-phase high-performance liquid chromatography. Anal Biochem 190, 120-128.

Henning, U., Rehn, K., Braun, V., Höhn, B. \& Schwarz, U. (1972). Cell envelope and shape of Escherichia coli K12: properties of a temperature-sensitive rod mutant. Eur J Biochem 26, 570-586.

Höltje, J.-V., Mirelman, D., Sharon, N. \& Schwarz, U. (1975). Novel type of murein transglycosylase in Escherichia coli. J Bacteriol 124, 1067-1076.

de Jonge, B. L. M., Wientjes, F. B., Jurida, I., Driehuis, F., Wouters, J. T. M. \& Nanninga, N. (1989). Peptidoglycan synthesis during the 
cell cycle of Escherichia coli: composition and mode of insertion. $J$ Bacteriol 171, 5783-5794.

Kohlrausch, U. \& Höltje, J.-V. (1991). Murein and murein precursor analysis during antibiotic-induced lysis of Escherichia coli.J Bacteriol 173, 3425-3431.

Korat, B., Mottl, H. \& Keck, W. (1991). Penicillin-binding protein 4 of Escherichia coli: molecular cloning of the dacB gene, controlled overexpression, and alterations in murein composition. Mol Microbiol 5, 675-684.

Kraus, W. \& Höltje, J.-V. (1987). Two distinct transpeptidation reactions during murein synthesis in Escherichia coli. J Bacteriol 169, 3099-3103.

Lleo, M. M., Canepari, P. \& Satta, G. (1990). Bacterial cell shape regulation: testing of additional predictions unique to the twocompeting-sites model for peptidoglycan assembly and isolation of conditional rod-shaped mutants from some wild-type cocci. $J$ Bacteriol 172, 3758-3771.

Markiewicz, Z. \& Höltje, J.-V. (1992). Failure to trigger the autolytic enzymes in minicells of Escherichia coli. FEMS Microbiol Lett 91, 19-124.

Mollner, S. \& Braun, V. (1984). Murein hydrolase ( $N$-acetylmuramyl-L-alanine amidase) in human serum. Arch Microbiol 140, 171-177.

Mukherjee, A., Das, K. \& Lutkenhaus, J. (1993). E. coli cell division protein FtsZ is a guanine nucleotide binding protein. Proc Natl Acad Si US A 90, 1053-1057.

Nanninga, N. (1988). Growth and form in microorganisms: morphogenesis of Escberichia coli. Can J Microbiol 34, 381-389.

Nanninga, N. (1991). Cell division and peptidoglycan assembly in Escherichia coli. Mol Microbiol 5, 791-795.

Nanninga, N., Wientjes, F. B., de Jonge, B. L. M. \& Woldringh, C. L. (1990). Polar cap formation during cell division in Escherichia coli. Res Microbiol 141, 103-118.

Park, J. T. \& Burman, L. G. (1973). FL 1060: a new penicillin with a unique mode of action. Biochem Biophys Res Commun 51, 863-868.

Pisabarro, A. G., Prats, R., Vazquez, D. \& Rodriguez, T. A. (1986). Activity of penicillin-binding protein 3 from Escherichia coli. $J$ Bacteriol 168, 199-206.

Raychaudhuri, D. \& Park, J. T. (1992). Escherichia coli cell-division gene $f t s Z$ encodes a novel GTP-binding protein. Nature 359, 251-254.

Reeve, J. N. (1977). Mucopeptide biosynthesis by minicells of Escherichia coli. J Bacteriol 131, 363-365.

Romeis, T., Kohlrausch, U., Burgdorf, K. \& Höltje, J.-V. (1991).
Murein chemistry of cell division in Eschericbia coli. Res Microbiol 142, 325-332.

Schanbacher, F. L. \& Ebner, K. E. (1970). Galactosyltransferase acceptor specificity of the lactose synthetase A protein. $J$ Biol Chem 245, 5057-5061.

Schindler, M., Mirelman, D. \& Schwarz, U. (1976). Quantitative determination of $N$-acetylglucosamine residues at the non-reducing ends of peptidoglycan chains by enzymic attachment of $\left[{ }^{14} \mathrm{C}\right]-\mathrm{D}-$ galactose. Eur J Biochem 71, 31-134.

Schwarz, U. \& Glauner, B. (1988). Murein structure data and their relevance for the understanding of murein metabolism in Escherichia coli. In Antibiotic Inbibition of Bacterial Cell Surface Assembly and Function, pp. 33-40. Edited by P. Actor, L. Daneo-Moore, M. L. Higgins, M. R. J. Salton \& G. D. Shockman. Washington, DC: American Society for Microbiology.

Schwarz, U. \& Leutgeb, W. (1971). Morphogenetic aspects of murein structure and biosynthesis. J Bacteriol 106, 588-595.

Schwarz, U., Asmus, A. \& Frank, H. (1969). Autolytic enzymes and cell division of Eschericbia coli. J Mol Biol 41, 419-429.

Schwarz, U., Seeger, K., Wengenmayer, F. \& Strecker, H. (1981). Penicillin-binding proteins of Escherichia coli identified with a ${ }^{125} \mathrm{I}$ derivative of ampicillin. FEMS Microbiol Lett 10, 107-109.

Spratt, B. G. (1975). Distinct penicillin binding proteins involved in the division, elongation, and shape of Escherichia coli K12. Proc Natl Acad Sci US A 72, 2999-3003.

Spratt, B. G. \& Pardee, A. B. (1975). Penicillin-binding proteins and cell shape in E. coli. Nature 254, 516-517.

Walderich, B., Ursinus-Wössner, A., van Duin, J. \& Höltje, J.-V. (1988). Induction of the autolytic system of Escherichia coli by specific insertion of bacteriophage MS2 lysis protein into the bacterial cell envelope. $J$ Bacteriol 170, 5027-5033.

Ward, J. E., Jr \& Lutkenhaus, J. (1985). Overproduction of FtsZ induces minicell formation in E. coli. Cell 42, 941-949.

Weidel, W. \& Pelzer, H. (1964). Bagshaped macromolecules - a new outlook on bacterial cell walls. Adv Enzymol 26, 193-232.

Wientjes, F. B., Woldringh, C. L. \& Nanninga, N. (1991). Amount of peptidoglycan in cell walls of Gram-negative bacteria. J Bacteriol 173, 7684-7691.

Woldringh, C. L., Huls, P., Pas, E., Brakenhoff, G. J. \& Nanninga, N. (1987). Topography of peptidoglycan synthesis during elongation and polar cap formation in a cell division mutant of Escherichic coli MC4100. J Gen Microbiol 133, 575-586.

Received 1 April 1993; revised 30 June 1993; accepted 3 August 1993. 